\title{
Supplementing female rats with DHA-lysophosphatidylcholine increases docosahexaenoic acid and acetylcholine contents in the brain and improves the memory and learning capabilities of the pups
}

\author{
By Alfonso Valenzuela, ${ }^{1 *}$ Susana Nieto, ${ }^{1}$ Julio Sanhueza, ${ }^{1}$ Nora Morgado, ${ }^{1}$ \\ Ingrid Rojas ${ }^{1}$ and Patricia Zañartu ${ }^{2}$
}

\author{
${ }^{1}$ Laboratorio de Lípidos y Antioxidantes, INTA, Universidad de Chile, Santiago, Chile \\ ${ }^{2}$ Escuela de Psicología, Universidad de los Andes, Santiago, Chile. \\ ( ${ }^{*}$ Corresponding author: avalenzu@inta.cl)
}

\section{RESUMEN}

La suplementación de ratas hembras con DHAlisofosfatidilcolina aumenta el contenido de ácido docosahexaenoico y de acetilcolina cerebral y mejora la capacidad de aprendizaje y de memorización de las crías

El ácido docosahexaenoico (DHA) que requiere el feto y el recién nacido lo aporta la madre desde sus reservas y la dieta, por lo cual se sugiere suplementar a la madre con DHA. No hay consenso sobre la mejor forma de suplementación. Proponemos que un lisofosfolípido que contiene DHA y colina (DHA-LPC) obtenido de huevos con alto contenido de DHA es adecuado para suplementar DHA y colina, precursora de la acetilcolina. Se evaluó la efectividad de DHA-LPC para incrementar el DHA y la acetilcolina cerebral de crías de ratas suplementadas con DHA-LPC antes y durante la gestación, y en la capacidad de aprendizaje y memorización de las crías mediante el test de condicionamiento operante de Skinner. Ratas Wistar hembras fueron suplementadas con DHA-LPC $(8 \mathrm{mg}$ $\mathrm{DHA} / \mathrm{kg} /$ día) 40 días antes y durante la preñez. Después del parto se analizó DHA en plasma, eritrocitos, hígado y tejido adiposo, y colina plasmática. A las crías de 60 días se les separó: corteza frontal, cerebelo, striatum, hipocampo y corteza occipital y se les analizó DHA, acetilcolina y la actividad de acetilcolina transferasa (CAT). Las crías fueron sometidas al test de Skinner. La suplementación con DHA-LPC aumenta la colina plasmática y el DHA hepático en las madres y el DHA y la acetilcolina del cerebelo e hipocampo en las crías. La actividad CAT no se modifica. Las crías de madres suplementadas con DHA-LPC mostraron puntajes de memorización y aprendizaje superior que las controles. Conclusión: el aporte de DHA y colina como DHA-LPC puede constituir una nueva forma para proveer suplementación prenatal con DHA.

PALABRAS-CLAVES: Acetilcolina cerebral - Colina Lisofosfolípidos - Suplementación con DHA - Test de Skinner.

\section{SUMMARY}

Supplementing female rats with DHAlysophosphatidylcholine increases docosahexaenoic acid and acetylcholine contents in the brain and improves the memory and learning capabilities of the pups

Docosahexaenoic acid (DHA) is supplied to the foetus and newborn through the mother from their own reserves and their diet. No consensus about the best form to supplement
DHA has been established. We propose that DHAcontaining lysophosphatidylcholine (DHA-LPC), obtained from DHA-rich eggs may be a suitable form of DHA and choline (the precursor of acetylcholine) supplementation. We evaluated the effectiveness of DHA-LPC to increase DHA and acetylcholine concentration in the brain of pups born from female rats supplemented with DHA-LPC before and during pregnancy. We also evaluated the effect of DHA supplementation on learning and memory capabilities of pups through the Skinner test for operant conditioning. Female Wistar rats received 40-day supplementation of DHA-LPC (8 $\mathrm{mg} \mathrm{DHA} / \mathrm{kg}$ b.w/daily.), before and during pregnancy. After delivery, plasma, erythrocyte, liver, and adipose tissue DHA and plasma choline were analyzed. Brains from 60 day-old pups separated into frontal cortex, cerebellum, striatum, hippocampus, and occipital cortex, were assessed for DHA, acetylcholine, and acetylcholine transferase (CAT) activity. Pups were subjected to the Skinner box test. DHA-LPC supplementation produces higher choline and liver DHA contents in the mother's plasma and increases the pups' DHA and acetylcholine in the cerebellum and hippocampus. CAT was not modified by supplementation. The Skinner test shows that pups born from DHA-LPC supplemented mothers exhibit better scores of learning and memory than the controls. Conclusion: DHA-LPC may be an adequate form for DHA supplementation during the perinatal period.

KEY-WORDS: Brain acetylcholine - Choline - DHA supplementation - Lysophospholipids - Skinner box test.

\section{INTRODUCTION}

The brain and retina of mammals contain very high amounts of long-chain polyunsaturated fatty acids (LC-PUFA), particularly arachidonic acid (20:4, omega-6, AA), and docosahexaenoic acid (22:6, omega-3, DHA) (Carlson \& Neuringer, 1999; Crawford, 2000). These fatty acids are formed from two dietary precursors; linoleic acid (18:3, omega-6, LA) for AA, and alpha-linolenic acid (18:3, omega-3, LNA) for DHA (Marszalek \& Lodish, 2005). LA is largely available from the normal western diet, and therefore $A A$ is not restrictive for brain and retina development (Simopoulos, 1999). However, the normal supply of 
LNA is frequently very low, and preformed DHA is even much lower (Crawford, 2000). DHA is present in large proportion in the grey matter of the brain's cerebral cortex, which constitutes $15-20 \%$ of the total fatty acids in the brain. It is believed that DHA plays an important role in regulating the fluidity of neuronal membranes, and thus the efficiency of neuroelectrical signal transmissions (Marszalek \& Lodish, 2005; Valenzuela, 2009). In humans, the highest amount of DHA is produced during the last trimester of pregnancy and also during the first two years of life (Clandinin, 1999; Wainwright, 2002). In the rat, the highest amount of DHA is produced from day 12 of gestation until the weaning of the pups (Martin \& Bazan, 1992). DHA is supplied to the foetus by the mother through the placenta during pregnancy and through the breast milk during nursing (Crawford, 2000). Mammalian milk contains a small but nutritionally significant amount of DHA (0.2-0.4\%), which is strongly dependent on the mother's availability of the fatty acid (or of its precursor, LNA) (Jensen, 1999). At present, formulas which replace breast milk contain added DHA in order to avoid a shortage of the fatty acid during pregnancy and nursing, mainly after frequent pregnancies and/or multiparous deliveries (Innis, 2004; Innis, 2007). DHA supplementation to the mother is now recommended during perinatal period (pregnancy and nursing), and even before the beginning of pregnancy (Salem et al, 2001). A mother's perinatal DHA supplementation has been associated with improved scores of memory and learning capabilities in humans (Willatts et al, 1998; Koo, 2003; Bakker et al., 2003; Judge et al., 2007; NEMO Study group, 2007), and in experimental animals such as rats (Moriguchi et al., 2000), and mice (Carrié et al., 2000), when evaluated through the Morris water maze test (Lim \& Suzuki, 2000; Suzuki et al., 2001), or the resolution radial 12 arms maze test (Carrié et al., 2002). Helland et al (2003) demonstrated that maternal omega-3 LC-PUFA supplementation during pregnancy and lactation increases children's IQ at 4 years of age.

Efforts have been made to provide perinatal DHA supplementation. DHA can be provided from various natural sources and in different degrees of purity: single-cell algae triacylglycerides (TG), egg yolk phospholipids (PL), pure DHA as an ethyl ester derivative (EE) and sn-2 docosahexaenyl monoacylglyceride (DHA-MG), are the main sources of DHA for perinatal supplementation (Garg et al., 2006; Valenzuela et al., 2006). We have comparatively evaluated the effect of these DHA sources in female Wistar rats when the fatty acid is supplied during the perinatal period, observing that DHA-MG appears to be the best supplementing source (Valenzuela et al., 2005). However, it has been demonstrated in rats that the blood transports DHA from the liver, which is the main physiological reservoir and source of the fatty acid, to the extra hepatic tissues is in the form of sn2 DHA lysophosphatidylcholine (DHA-LPC), which is highly permeable to the placenta and therefore, highly available for DHA accretion by the foetus (Thiés et al., 1992; Lemaitre-Delaunay et al., 1999; Lagarde et al., 2001). DHA-LPC simultaneously provides DHA and choline, the precursor of the neurotransmitter acetylcholine which is involved in memory and learning. Therefore, using the rat as an experimental model, in this report we analyzed the effect of DHA supplementation of mothers with DHA-LPC, obtained from commercial DHA-enriched eggs and compared to DHA-MG, in the DHA accretion and acetylcholine content in different brain segments of the pups, and in the memory and learning capabilities of the pups evaluated through the Skinner test of operant conditioning.

\section{MATERIALS AND METHODS}

\subsection{Materials}

Components of the synthetic diet were locally purchased. Solvents and reagents were obtained from Merck Química Chilena (Santiago, Chile). Fatty acid standards for gas-chromatography and reagents for fatty acid methyl ester derivative preparation were obtained from Sigma Chemical, St. Louis, MO, USA. sn-2 Monooleyltriacylglycerol (O-MG) was purchased from Nu-Check Prep (Elysian, MN, USA). DHA-MG (96\% pure, 60.9\% $\mathrm{DHA}, 80.4 \%$ at the sn-2 position was prepared according the procedure of Nieto et al., (1999). Immobilized Fungamyl 2799 (10,000 units/mg), prepared by Novo Nordisk, Denmark was a gift from Novo Brasil (Sao Paulo, Brasil). Coconut oil triacylglyceride fraction $(0.2 \%$ all-rac-alpha tocopherol) was a gift from Laboratorio Andrómaco (Santiago, Chile). Skinner boxes $(30 \times 10 \times 25 \mathrm{~cm})$ (two) and pellets for the operant conditioning test were purchased from Letica, Barcelona, España.

\subsection{Animals, diet, and supplementing protocols}

Recently weaned female Wistar rats (22-25 dayold, $n=45$ ) weighing $75-85 \mathrm{~g}$ were fed a synthetic diet as described by Watkins et al (2000). The diet contained $8 \%$ vegetable fat composed of a mixture of olive oil, sunflower oil, and soybean oil (saturated, monounsaturated, and polyunsaturated fatty acids $1: 1: 1 \mathrm{w} / \mathrm{w}$, omega-6/omega-3 ratio $10: 1)$. The formula provided $0.26 \mathrm{~g} / 100 \mathrm{~g}$ of LNA to their diet, and virtually $0 \mathrm{~g}$ DHA. Animals were separated into three experimental groups $(n=15$ each), and received the diet for a 40-day period. Supplementation was initiated at day 40 of feeding the synthetic diet. DHA-MG and DHA-LPC groups were daily supplemented to an amount which provided $8 \mathrm{mg} / \mathrm{kg}$ b.w. of DHA (which is close to the suggested supplementation of DHA for women, Simopulos et al., 1999). The control group was supplemented daily with $\mathrm{O}-\mathrm{MG}$ to an amount equivalent to $8 \mathrm{mg} / \mathrm{kg}$ b.w of oleic acid. Oils were given by gastric instillation dissolved in a triacylglyceride fraction of coconut oil into a volume 
which provided $8 \mathrm{mg} / \mathrm{kg}$ of DHA or oleic acid in 1.0 $\mathrm{mL}$. Animal weight was controlled every morning at 9:00 before instillation to calculate the amount of oil to be supplied. At day 40 of DHA-supplementation rats from each group were mated (three females were caged with one male) and once fecundation took place (by the observation of sperm from vaginal samples under microscope) female rats were reincorporated into their respective experimental group, restarting the supplementation until delivery. Immediately after delivery, 5 mothers from each experimental group were sacrificed by decapitation under light anaesthesia to obtain blood, liver, and retroperitoneal adipose tissue. Blood was separated by centrifugation for the evaluation of plasma choline concentration. Lipids were extracted from plasma, erythrocytes, liver, and adipose tissue samples, for fatty acid composition. The remaining mothers were allowed to freely nurse their pups. After weaning, male pups selected by similar weight were separated from mothers in separate cages according to their experimental group (10 animals/cage) and fed the synthetic diet. At day-60 ten animals from each experimental group were sacrificed by decapitation under light anaesthesia to remove the brain for further analysis. Frontal cortex, cerebellum, striatum, hippocampus, and occipital cortex were rapidly excised for determination of acetylcholine concentration and choline acetyltransferase activity (CAT) and processed for total lipid extraction for fatty acid composition analysis. The remaining animals were subjected to the Skinner box test for operant conditioning (Staddon \& Cerutti, 2003).

\subsection{Skinner box test}

Three walls of each box were non transparent (black) and the front wall transparent. Animals, previously fasted over night, were subjected to a week of training (20 minutes/day) to familiarize themselves with the association "pressing the lever and obtaining pellet". The light inside the box remained off during training. This was defined as the pre-conditioning test period. After this period, animals were trained for another week to associate "pressing the lever and obtaining pellet" which only occurs when the light inside the Skinner box was on. This was the operant conditioning test period (Staddon \& Cerutti, 2003). After these assays were performed, animals were returned to their cages for a 5-day period. After this wash-out period animals fasted over-night were subjected again to the operant conditioning test (association pressing the lever and obtaining pellet when light is on). This was the latency to the operant conditioning. For each assay a score was established for positive responses (ie, pressing the lever and obtaining pellet and pressing the lever and obtaining pellet when the light is on) expressed as percentage of successful tasks against the total tries in a ten minute assay period. The pre-conditioning test and the operant conditioning test allow for the evaluation of learning capabilities (Sloan et al., 2006). The latency to the operant conditioning is a measurement of the retained capabilities (memory) to previously learned operations (Massaro \& Widmayer, 1981; Tikhonrarov, 2000). The care of animals during each experimental period was in compliance with the Guidelines of the Research Scientific Council of the University of Chile for Animal Care and Use.

\section{4. Analytical procedures}

DHA-LPC was prepared from DHA-rich phosphatidylcholine obtained from omega-3 commercial eggs (250 mg DHA/egg, Agrícola Nutraomega, Santiago, Chile) by a modification of the enzymatic procedure described by Sonada et al (2002) using Fungamyl 2599. Plasma choline concentration was measured according the enzymatic procedure of Ozarda et al., (2003) which uses choline kinase and ${ }^{32}$ P-ATP. Acetylcholine from brain segments was measured by the HPLC procedure described by Auld et al., (2001). CAT activity was evaluated according the method of Smith et al., (2004) using ${ }^{3} \mathrm{H}$-acetyl-CoA as substrate. Total lipids from the brain segments were extracted according to Folch et al., (1957). A measurement of total phospholipids from the lipid extracts was estimated from the measurement of total phosphorus (Pi) as described by DuckChong (1979). Methyl ester derivatives of the lipids extracted from plasma, erythrocytes, liver, adipose tissue and each brain segment were prepared according to the method of Morrison and Smith (1964). Gas chromatography was performed in an Agilent $6890 \mathrm{~N}$ gas chromatograph equipped with a slit injector, using an SP-2560 capillary column (30m x $0.25 \mathrm{~mm}$ inner diameter, Supelco, Bellefonte, PA, USA) The column temperature was increased from $140^{\circ} \mathrm{C}$ to $240^{\circ} \mathrm{C}$ at $2^{\circ} \mathrm{C}$ per min and the detector temperature was $260^{\circ} \mathrm{C}$. Hydrogen gas was used as carrier and tricosanoic acid (23:0) as internal standard.

\subsection{Expression of results and statistics}

Plasma choline concentration was expressed as nmoles/L. Brain acetylcholine concentration was expressed as nmoles/g wet tissue. CAT activity was expressed as nmoles ${ }^{3} \mathrm{H}$-acetate/mg of protein/hour. $\mathrm{AA}$ and DHA concentrations were expressed as: ug/ $\mathrm{mL}$ for plasma; ug/mg tissue for adipose tissue; $\mathrm{mg} /$ total phospholipids for liver and erythrocytes; and $\mathrm{mg} / 100 \mathrm{mg}$ total phospholipids for brain segments. The results represent the average $\pm S D$. Statistical significance of differences between mean values was assessed by analysis of variance coupled to Duncan's multiple range test (Duncan, 1957). Significance was set at $p<0.05$. * Notation was used for significant differences of DHA-supplements and the control and ** notation for significant difference between supplements. 


\section{RESULTS}

Figure 1 shows plasma choline concentration obtained from mothers at delivery after DHA-MG and DHA-LPC supplementation. As can be observed, DHA-MG does not produce any modification of plasma choline. However, DHA-LPC supplementation produces a significant increase in plasma choline concentration.

Figure 1

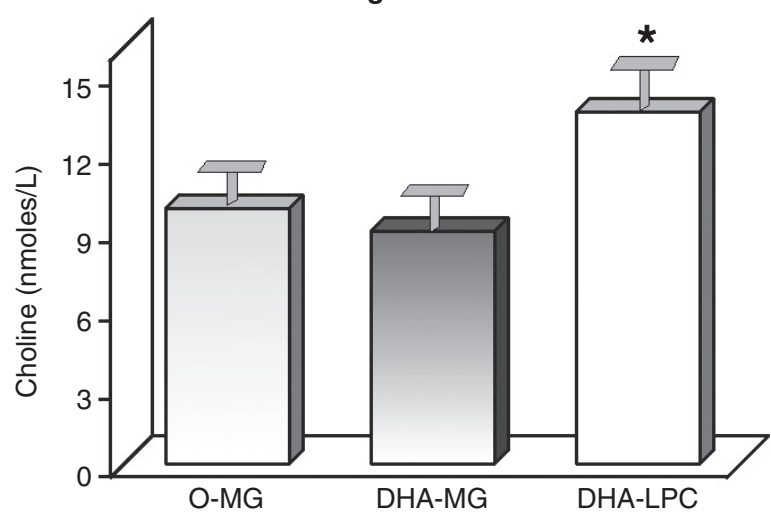

* = Significantly different from O-MG and DHA-MG, $\mathrm{p}<0,05$

Plasma choline concentration of mothers upon delivery after DHA-MG and DHA-LPC supplementation.

Figure 2 shows $A A$ and DHA contents in plasma triacylglycerides $(A)$, adipose tissue $(B)$, liver $(C)$ and erythrocytes (D) of samples obtained from DHA-supplemented mothers at delivery. Plasma triacylglycerides, adipose tissue and erythrocytes show similar levels of DHA when both supplementing sources are compared, being significantly higher than the control. These results demonstrate that DHA, when provided either as DHA-MG or DHALPC is similarly incorporated into these tissues. AA levels are not modified by supplementation. Liver shows a different behavior because DHA-LPC

Figure 2
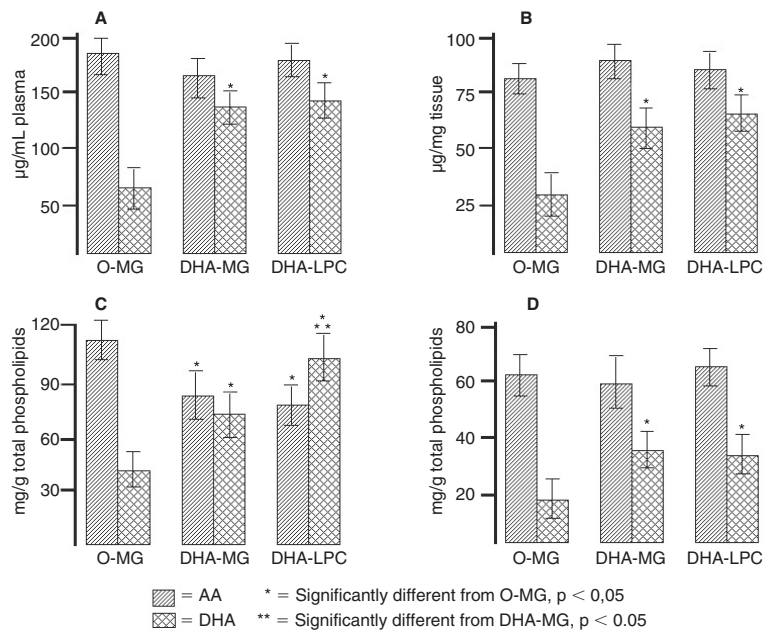

$A A$ and DHA content of plasma triacylglycerides $(A)$, adipose tissue (B), liver (C) and erythrocytes (D) of samples obtained from DHA-MG and DHA-LPC supplemented mothers after delivery. supplementation allows for a higher content of DHA than DHA-MG supplementation. This is important because liver has a pivotal importance in the distribution of LC-PUFA to extra hepatic tissues during pregnancy, specifically to the placenta (Dutta-Roy, 2000). A higher hepatic DHA content may produce a better efficiency in the delivery of the fatty acid to peripheral tissues. This may represent a physiological advantage for DHA-LPC supplementation compared to DHA-MG supplementation. As DHA concentration increases in the liver, AA concentration is reduced. This effect may result from the competition of these two fatty acids for the same substituting position in hepatic phospholipids. AA may be substituted, either at the sn-1 or sn-2 position of phospholipids. However DHA preferentially occupies the sn-2 position, therefore displacing AA from this position (Marszalek \& Lodish, 2005).

Figure 3 shows $A A$ and DHA contents in phospholipids extracted from the frontal cortex (A), cerebellum (B), striatum (C), hippocampus (D) and occipital cortex (E) obtained from the pups delivered by mothers supplemented with DHA-MG or DHA-LPC. As can be observed, both supplements increase the DHA content in the brain segments analyzed. However, differences are observed for the cerebellum and hippocampus. At these brain segments, DHA-LPC supplementation allows a higher accretion of DHA than DHA-MG supplementation. AA concentration is not modified, showing similar levels to the control in the brain segments analyzed.

Figure 4 shows acetylcholine concentration of the different brain segments obtained from the pups. It is interesting that DHA-LPC increases the concentration of the neurotransmitter at the frontal cortex, cerebellum and hippocampus, not modifying the acetylcholine concentration in the striatum and occipital cortex. When compared to the control, DHA-MG supplementation does not produce any modification of acetylcholine concentration in the brain segments studied.

Figure 5 shows CAT activity in the brain segments removed from the pups. This important

Figure 3

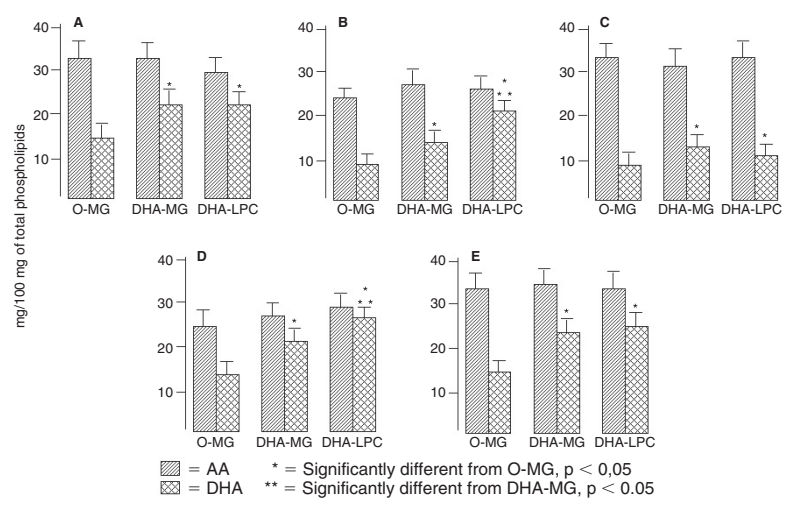

$A A$ and DHA content of phospholipids extracted from frontal cortex (A), cerebellum (B), striatum (C), hippocampus (D) and occipital cortex $(E)$, obtained from pups delivered by mothers supplemented with DHA-MG or DHA-LPC. 
Figure 4

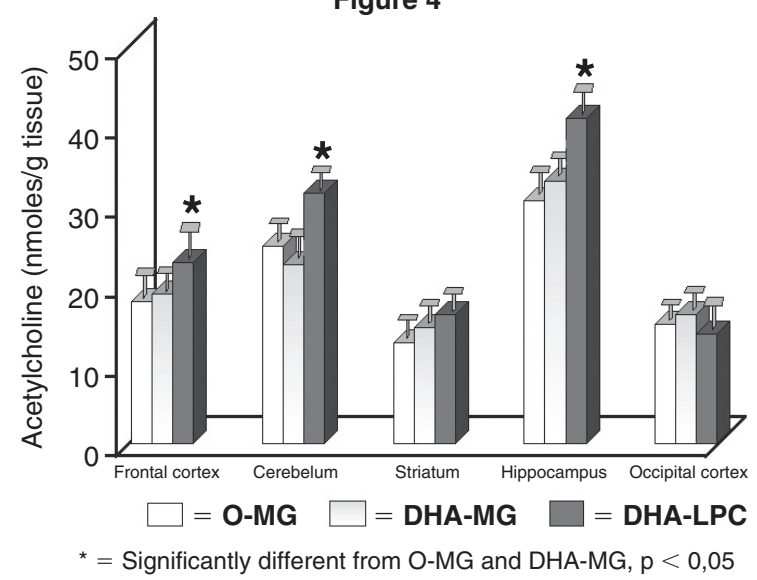

Acetylcholine concentration of the different brain segments obtained from pups delivered by DHA-MG and DHA-LPC supplemented mothers.

Figure 5

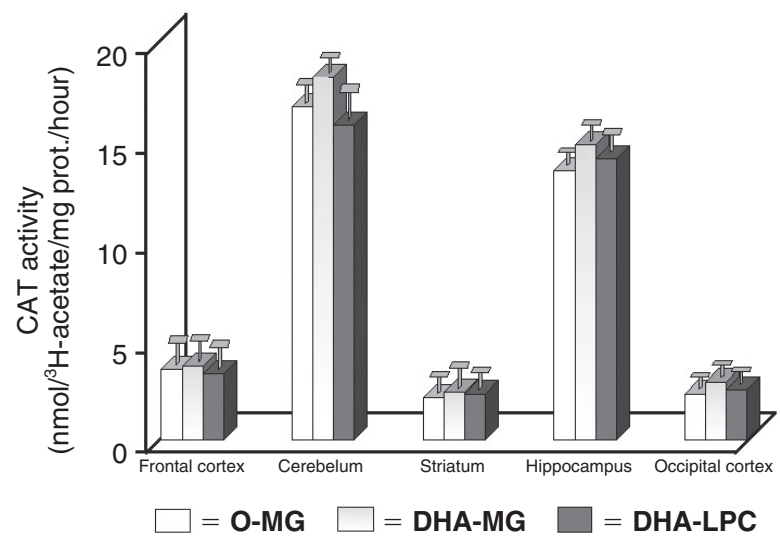

Choline acetyl transferase (CAT) activity of the brain segments obtained from pups delivered by DHA-MG and DHA-LPC supplemented mothers.

enzyme, which is involved in the biosynthesis of acetylcholine, shows different levels of enzymatic activity in the different brain segments. Higher values for cerebellum and hippocampus are observed, with a small and almost similar activity in the frontal cortex, striatum and occipital cortex. DHA supplementation does not modify the activity of the enzyme. This differential effect can be interpreted as follows; the higher concentration of acetylcholine observed at the frontal cortex, cerebellum, and hippocampus after DHA-LPC supplementation results from the higher availability of choline provided by DHA-LPC as substrate for the enzyme and not from a higher activity of the enzyme in these brain segments.

Figure 6 shows results obtained from the Skinner box test after the pre-conditioning training test, the operant conditioning training test and the latency to the application of the operant conditioning test. DHA-LPC supplementation produced a higher score of positive responses at the three modalities of the test. DHA-MG produces only a better response than the control at the preconditioning training test.
Figure 6

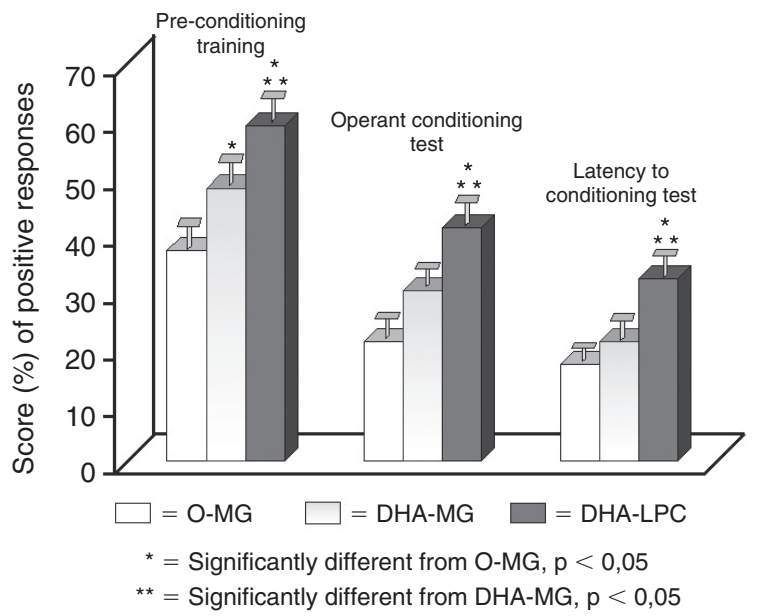

Score of positive responses for the Skinner test (preconditioning training test, operant conditioning test and latency to conditioning test) of pups delivered by DHA-MG and DHALPC supplemented mothers.

\section{DISCUSSION}

After the suggestion of Expert Committees to include omega-3 LC-PUFA in infant formulas (Simopoulos et al., 1999), efforts were made to identify suitable sources for DHA supplementation. Refined and deodorized fish oil was initially used because of its availability and relative high content of DHA. However, fish oil contains EPA which has been implicated in adverse effects in the growth of premature infants (Carlson \& Neuringer, 1999). Therefore new sources were developed. At present, DHA is available from as single cell algae oil, free DHA or the ethyl ester derivative, from egg phospholipids, or as monoacylglyceride. Algae oil is expensive, ethyl esters have low availability, phospholipids are not generally accepted (these are frequently used in Europe but not in the Americas) and monoacylglycerides are experimental products at present not available as commercial products (Valenzuela et al., 2006). We focussed on phospholipids for two reasons. First, in mammalian tissues DHA is mainly acylated to phospholipids and not to triacyglycerides (Holub, 1978). Second, technologically, phospholipids easily form water-oil emulsions which allow their incorporation to different water-containing food matrixes. This is very important when DHA, as a nutritional supplement, must be added to fluid milk, yogurt, juices, etc (Valenzuela et al., 2006). Intestinal absorption of phospholipids needs previous hydrolysis by a phospholipase to be converted into lysophospholipids, which are further resterified at the intestinal cells and finally transported into quilomicrons to peripheral tissues, finally returning to the liver as remnant chylomicrons (Kritchevsky, 1995). The liver constantly releases lysophospholipids, mainly lysophosphatidylcholine, which are bound to plasma albumin and delivered to different tissues (Thies et al., 1992). During pregnancy, the liver releases DHA-LPC and in less proportion DHA-lysophosphatidylserine which are 
directed to the placenta providing DHA that is accreted at the foetal brain and selectively incorporated into neuronal membranes, synaptosomes and growth cone mobility (Suzuki et al., 1997). Analyses of specific brain regions in rats supplemented with $\mathrm{DHA}$ have demonstrated that $\mathrm{DHA}$ is preferentially accreted in the frontal cortex, cerebellum and hippocampus (Valenzuela et al., 2004), such as we have observed in this report. Because of these biochemical and physiological characteristics of lysophospholipids, we hypothesized that DHA-LPC should be a suitable source for DHA supplementation.

Choline is an essential nutrient for mammals needed for the structural integrity and signal functions of cell membranes, for normal cholinergic neurotransmission, for normal muscular function, for lipid transport from liver and is the major source of the methyl group in the diet (Zeisel 2000; Zeisel, 2006). Choline, through the action of CAT is transformed into acetylcholine, the main molecule involved in central and peripheral neurotransmission (Everett \& Robins, 1997). The cholinergic cells of the hippocampus are related to the learning and memory capabilities of the brain (Ragozzino et al., 1996; Das, 2003). Choline supplementation during the gestational period increases the sensibility of hippocampus neurons to stimulus (López et al., 1992), increases the concentration of acetylcholine at the frontal cortex and hippocampus (Jones et al., 1999), regulates the cellular cycle and neuronal apoptosis during brain development (Craciunescu et al., 2003) and increases the size of cholinergic hippocampus neurons (Loy et al., 1991). Acetylcholine, like other neurotransmitters, plays an important role in neurite outgrowth, growth cone motility, target cell selection and synaptogenesis (Spencer et al., 1998; Weiss et al., 1998). Many studies have demonstrated that dietary supplementation with phosphatidylcholine increases brain acetylcholine concentration and improve memory impairment in young and aged animals (Leathwood et al., 1982; Chung et al., 1995).

By an enzymatic procedure we have obtained DHA-LPC from DHA enriched commercial eggs. Thus, through the same molecule, the lysophospholipid simultaneously provides DHA and choline for supplementation. Our results demonstrate that supplementing mothers with DHA-LPC produce higher plasma choline concentrations in the mothers, and higher acetylcholine concentrations in the cerebellum and hippocampus of the pups, in addition to the better accretion of DHA obtained in the same brain segments when compared to DHAMG. Favreliere et al (2003) obtained similar results with pups when they assayed the supplementation of mothers with phospholipids obtained from DHArich eggs. It has been described that DHA per se increases brain acetylcholine (Minami et al., 1997). However, in our protocol the increase in acetylcholine observed after DHA-LPC supplementation appears to be a specific effect of choline provided by the supplement.

Previous assays to evaluate animal behaviour after DHA supplementation have been performed using the Morris water maze test (Lim \& Suzuki, 2000; Suzuki et al., 2001), or the radial arm-maze test (Carrié et al., 2002). Both tests are primarily used to evaluate the working memory and do not allow the evaluation of capabilities under more complex conditioning situations (Jonasson, 2005), such as pellet supply when the light is on in the Skinner box. Therefore, in our opinion, the Skinner test provides a more suitable procedure to evaluate learning and memory capabilities. Results from the Skinner test for operant conditioning demonstrated that pups from DHA-LPC supplemented mothers show improved learning (pre-conditioning and operant conditioning tests) and memory (latency to pre-conditioning test) than pups nursed by mothers supplemented with DHA-MG and the control oil. A number of reports establish that DHA supplementation increases neurite outgrowth that needs higher levels of DHA in the growth cone, which is important during neurodevelopment and for the acquisition of learning and memory capabilities (Martin \& Bazan, 1992; Innis \& De la Presa, 2001). According to our information, this is the first time that the Skinner test is applied to an omega-3 fatty acid supplementing protocol. Through the use of DHA-LPC as a nutritional supplement, we combined the beneficial effect of choline and DHA supplementation, increasing the learning and memory capabilities of pups from mothers that received the supplement during the perinatal period. Maternal supplementation with DHA during pregnancy and lactation may increase children's intelligence, as was demonstrated by Heland et al., (2003). DHA-LPC appears to be a good source of DHA and choline. In summary, we propose that DHA-LPC may constitute an adequate experimental form to provide both DHA and choline supplementation during the perinatal period. However, further assays are needed to validate the future of DHA-LPC as the best way to provide DHA supplementation into infant formulas. We are currently working on this issue.

\section{ACKNOWLEDGMENTS}

This research was partially supported by FONDECYT (project 1050515) and INNOVACORFO. We are greatly indebted to the students from Escuela de Psicología, Universidad de los Andes, who participated in the training of the rats for the Skinner test.

\section{REFERENCES}

Auld D, Menniken F, Day J, Quirion R. 2001. Neurothrofins differentially enhance acetylcholine release, acetylcholine content and choline acetyltransferase activity in basal forebrain neurons. J. Neurochem. 77, 253-258.

Bakker EC, Ghys A J, Kester AD, Vies JS, Blanco CE, Hornstra G. 2003. Long-chain polyunsaturated fatty acids at birth and cognitive function at 7 years of age. Eur. J. Clin. Nutr. 57, 89-95. 
Carlson S, Neuringer M. 1999. Polyunsaturated fatty acid status and neurodevelopment: a summary and critical analysis of the literature. Lipids 34, 171-178.

Carrié I, Guesnet P, Bourre JM, Francés H. 2000. Diets containing long-chain polyunsaturated fatty acids affect behaviour differently during development than ageing mice. Brit. J. Nutr. 83, 439-447.

Carrié I, Smirnova N, Clément M, De Javel D, Francés H, Bourre JM. 2002. Docosahexaenoic acid-rich phospholipid supplementation: effect on behaviour, learning ability, and retinal function in control and n-3 polyunsaturated acid deficient old mice. Nutr. Neurosci. 5, 43-52.

Chung SY, Moriyama T, Uezu E, Uezu K, Hirata R, Yohena N, Masuda Y, Kokubu T, Yamamoto S. 1995. Administration of phosphatidylcholine increases brain acetylcholine concentration and improves memory in mice with dementia. J. Nutr. 125, 1484-1489.

Clandinin T. 1999. Brain development and assessing the supply of polyunsaturated fatty acids. Lipids 34,131 137.

Craciunescu C, Albright C, Mar MH, Song J, Zeisel S. 2003. Choline availability during embryonic development alter progenitor cell mitosis in developing mouse hippocampus. J. Nutr. 133, 36143618.

Crawford M. 2000. Placental delivery of arachidonic and docosahexaenoic acids: implications for the lipid nutrition of preterm infants. Am. J. Clin. Nutr. 71 (suppl) 275S-284S.

Das UN. 2003. Long-chain polyunsaturated fatty acids in memory formation and consolidation: further evidence and discussion. Nutrition 19, 988-993.

Duck-Chong CG. 1979. A rapid sensitive method for determining phospholipids phosphorus involving the digestion of magnesium. Lipids 14, 492-497.

Duncan DB. 1957. Multiple range test for correlated heterocedastics means. Biometrics 13, 164-176.

Dutta-Roy AK. 2000. Transport mechanism for long-chain polyunsaturated fatty acids in the human placenta. Am. J. Clin. Nutr. 71, 315S-322S.

Everett B J, Robbins TW. 1997. Central cholinergic system and cognition. Annu. Rev. Psychol. 48, 649681.

Favreliere S, Perault MC, Huguet $F$, De Javel $D$ Bertrand N, Piriod A, Durand G. 2003. DHA-enriched phospholipids diets modulate age-related alterations in rat hippocampus. Neurobiol. Aging. 24, 2333-2343.

Folch J, Lees M, Sloane-Stanley GH. 1957. A simple method for the isolation and purification of lipids from animal tissues. J. Biol. Chem. 22, 497-509.

Garg ML, Wood LG, Mougham P. 2006. Means of delivering recommended levels of long chain $n-3$ polyunsaturated fatty acids in human diets. J. Food Sci. 71, R66-R71.

Helland IB, Smith L, Saarem K, Saugstad OD, Drevon CA. 2003. Maternal supplementation with very-longchain n-3 fatty acids during pregnancy and lactation augments children's IQ at 4 years of age. Pediatrics 111, e39-e44.

Holub BJ. 1978. Differential utilization of 1-palmitoyl and 1-stearoyl homologues of various unsaturated 1,2-diacyl-sn-glycerols for phosphatidylcholine and phosphatidylethanolamine synthesis in rat liver microsomes. J. Biol. Chem. 253, 691-696.

Innis SM, De la Presa S. 2001. Dietary fatty acid composition in pregnancy alters neurite membrane fatty acids and dopamine in newborn rat brain. J. Nutr. 131, 118-122.
Innis SM. 2004. Polyunsaturated fatty acids in human milk: an essential role in infant development. Adv. Exp, Med. Biol. 554, 27-43.

Innis SM. 2007. Human milk: maternal dietary lipids and infant development. Prod. Nutr. Soc. 66, 397-404.

Jensen RG. 1999. Lipids in human milk. Lipids 34, 12431271.

Jonasson Z. 2005. Meta-analysis of sex differences in rodent models of learning and memory: a review of behavioral and biological data. Neurosci. Beaviour. Rev. 28, 811-825.

Jones J, Meck W, Williams W, Wilson W, Swartzwelder H. 1999. Choline availability to the developing rat fetus alters adult hippocampal long-term potentiation. Brain Res. Dev. 118, 159-167.

Judge M, Harel O, Lammi-Keefe C. 2007. Maternal consumption of docosahexaenoic acid-containing functional foods during pregnancy: benefit for infant performance on problem-solving but not on recognition memory tasks at age $9 \mathrm{mo}$. Am. J. Clin. Nutr. 85, 1572-1577.

Koo W. 2003. Efficacy and safety of docosahexaenoic acid and arachidonic acid addition to infant formulas: can one buy better vision and intelligence? Am. J. Coll. Nutr. 22, 101-107.

Kritchevsky D. 1995. Fatty acids, triglyceride structure, and lipid metabolism. Nutr. Biochem. 6, 172-178.

Lethwood P D, Heck E, Mauron J. 1982. Phosphatidylcholine and avoidance performance in 17 month-old SEC/IReJ mice. Life Science 30, 1065-1071.

Lagarde $M$, Bernoud N, Brossard N, LemaitreDelaunay D, Thiés F, Croset M, Lecerf J. 2001. Lysophosphatidylcholine as a preferred carrier form of docosahexaenoic acid to the brain. J. Mol. Neurosci. 16, 201-205.

Lemaitre-Delaunay D, Pachiaudi C, Laville M, Pousin J, Armstrong M, Lagarde M. 1999. Blood compartmental metabolism of docosahexaenoic acid (DHA) in humans after ingestion of a single dose of [(13)C]DHA in phosphatidylcholine. J. Lipid Res. 40, 1867- 1874.

Lim SY, Suzuki H. 2000. Intakes of dietary docosahexaenoic acid ethyl-ester and egg phosphatidylcholine improve maze-learning ability in young and old mice. J. Nutr. 130, 1629-1632.

López I, Agut J, Ortiz A, Wurtman R. 1992. Effects of orally administered cytidine 5'- diphosphatecholine on brain phospholipid content. J. Nutr. Biochem. 3, 313315.

Loy R, Heyer D, Williamd C, Meck WH. 1991. Cholineinduced spatial memory facilitation correlates with altered distribution and morphology of septal neurons. Adv. Exp. Med. Biol. 295, 373-382.

Marszalek J R, Lodish HF. 2005. Docosahexaenoic acid, fatty acid-interacting proteins, and neuronal function: breast milk and fish are good for you. Annu. Rev. Cell. Dev. Biol. 21, 633-657.

Martin RE, Bazan NG. 1992. Changing fatty acid content of growth cone lipids prior to synaptogenesis. J. Neurochem. 59, 318-325.

Massaro TF, Widmayer P. 1981. The effect of iron deficiency on cognitive performance in the rat. Am. J. Clin. Nutr. 34, 864-870.

NEMO Group Study. 2007. Effect of a 12-mo micronutrient intervention on learning and memory in well-nourished and marginally nourished school-aged children: 2 parallel randomized, placebo-controlled studies in Australia and Indonesia. Am. J. Clin. Nutr. 86, 1082-1093. 
Minami M, Kimura S, Endo T, Hamaue N, Hirafuji M, Togashi $H$, Matsumoto $M$, Yoshioka $M$, Saito $H$, Watanabe S, Kobayashi T, Okuyama H. 1997. Dietary docosahexaenoic acid increases cerebral acetylcholine levels and improves passive avoidance performance in stroke-prone spontaneous hypertensive rats. Pharmacol. Biochem. Behav. 58, 1123-1129.

Moriguchi T, Greiner R, Salem N. 2000. Behavioral deficits associated with dietary induction of decreased brain docosahexaenoic acid concentration. J. Neurochemistry 75, 2563-2573.

Morrison W, Smith LM. 1964. Preparation of fatty acid methyl esters and dimethyl acetals form lipids with boron fluoride-methanol. J. Lipid Res. 25, 600-608.

Nieto S, Gutiérrez J, Sanhueza J, Valenzuela A. 1999. Preparation of sn-2 long-chain polyunsaturated monoacylglycerols from fish oil by hydrolysis with a stereo-specific lipase from Mucor miehei. Grasas \& Aceites 50, 111-113.

Ozarda Y, Gurun MS, Taga Y, Ulus I. 2003. Choline increases serum insulin in rat when injected intraperitoneally and augment basal and stimulated acetylcholine release from the rat minced pancreas in vitro. Eur. J. Biochem. 270, 991-997.

Ragozzino M E, Unik KE, Gold PE. 1996. Hippocampal acetylcholine release during memory testing in rats: augmentation by glucose. Proc. Natl. Acad. Sci. 16 243-261.

Salem N, Litman B, Kim HY, Gawrish K. 2001. Mechanism of action of docosahexaenoic acid in the nervous system. Lipids 36, 945-959.

Simolopulos AP. 2002. The importance of the ratio of omega-6/omega-3 essential fatty acids. Biomed. Pharmacother. 56, 365-379.

Simopoulos A, Leaf A, Salem N. 1999. Essentially and recommended dietary intakes for omega- 6 and omega-3 fatty acids. Ann. Nutr. Metab. 43, 127-130.

Smith, J., Vaughn, T., Co, C. (2004). Acetylcholine turnover rates in rat brain regions during cocaine selfadministration. J. Neurochem. 88, 502-512.

Sonada, H., Aoki, J., Hiramatsu, T., Isgida, M., Bandoh, K., Nagai, Y. (2002). A novel phosphatidic acid-selective phospholipase A1 that produced lysophosphatidic acid. J. Biol. Chem. 277, 34254-34263.

Sloan, H., Dobrossy, M., Dunnett, S. B. (2006). Hippocampal lesion impairs performance on a conditional delayed matching and non-matching to position task in the rat. Behav. Brain Res. 171, 240-250.

Spencer GE, Klumperman J, Syed NI. 1998. Neurotransmitter and neurodevelopment. Role of dopamine and acetylcholine in neurite outgrowth, target selection and specific synapse formation. Perspect. Dev. Neurobiol. 5 , 451-467.

Staddon JE, Cerutti DT. 2003. Operant conditioning. Annu. Rev. Psychol. 54, 115-144.

Suzuki H, Manabe S, Wada O, Crawford MA. 1997. Rapid incorporation of docosahexaenoic acid from dietary sources into brain microsomal, synaptosomal and mitochondrial membranes in adult mice. Int. J. Vit. Res. 67, 272-278.
Suzuki S, Yamatoya H, Sakai M, Kataoka A, Furushiro M, Kudo S. 2001. Oral administration of soybean lecithin transphosphatidylated phosphatidylserine improves memory impairment in aged rats. J. Nutr. 131, 2951-2958.

Thiés F, Delachambre MC, Bentejac M, Lagarde M, Lecerf J. 1992. Unsaturated fatty acids esterified in 2-acyl-1-lysophosphatidylcholine bound to albumin are more efficiently taken up by the young rat brain than the unesterified form. J Neurochem. 59, 11101116.

Tikhonrarov DL. 2000. Involvement of the parafascicular nucleus of the thalamus and the cholinoreactive systems of the neostriatum in controlling a foodprocuring reflex in rats at different stages of learning. Neurosci. Behav. Physiol. 30, 391-398.

Valenzuela $A$, von Bernhardi $R$, Valenzuela $V$, Ramírez G, Alarcón R, Sanhueza J, Nieto S. 2004. Supplementation of female rats with alpha-linolenic acid or docosahexaenoic acid leads to the same omega-6/omega-3 LC-PUFA accretion in mother tissues and newborn brains. Ann. Nutr. Metab. 48, 28-35.

Valenzuela A, Nieto S, Sanhueza J, Núñez MJ, Ferrer C. 2005. Tissue accretion and milk content of docosahexaenoic acid (DHA) in female rats after supplementation with different sources of DHA. Ann. Nutr. Metab. 49, 325-332.

Valenzuela A, Sanhueza J, Nieto S. 2006. Docosahexaenoic acid (DHA), essentiality and requirements: why and how to provide supplementation. Grasas \& Aceites, 57, 229237.

Valenzuela A. 2009. Docosahexaenoic acid (DHA), an essential fatty acid for the proper functioning of neuronal: their role in mood disorders. Grasas \& Aceites, 60, 203-212.

Wainwright P. 2002. Dietary essential fatty acids and brain function: a developmental perspective on mechanism. Proc. Nutr. Soc. 61, 61-69.

Weiss ER, Maness PA, Lauder JM. 1998. Why do neurotransmitters act like growth factores? Perspect. Dev. Neurobiol. 5, 323-335.

Watkins B, Li Y, Allen K, Hoffmann W, Seifert M. 2000. Dietary ratio of $n-6$ and $n-3$ polyunsaturated fatty acids alters the fatty acid composition of bone compartments and biomarkers of bone formation in the rat. J. Nutr. 130, 2274-2278.

Willatts P, Forsyth J, DiModugno M, Varma S, Colvon M. 1998. Effect of long-chain polyunsaturated fatty acids in infant formula on problem solving at 10 month of age. Lancet, 352, 688-691.

Zeisel S. 2000. Choline: an essential nutrient for human. Nutrition 16, 669-671.

Zeisel S. 2006. Choline: critical role during fetal development and dietary requirements in adults. Annu. Rev. Nutr. 26, 229-250. 